\title{
DEVELOPING BLENDED LEARNING APPLICATION UTILIZING ARTICULATE STORY LINE 3.0 INTREGRATED WITH ANDROID BASED SYSTEM
}

\author{
Efrizal Siregar, Nurianti Sitorus, Juwariah \\ Teknik Grafika \\ Politeknik Negeri Media Kreatif \\ https://polimedia.ac.id/ \\ efrizal_siregar@polimedia.ac.id, nurianti_torus@polimedia.ac.id,juwariah@polimedia.ac.id \\ (*) Corresponding Author
}

\begin{abstract}
Abstrak
Perkerkembangan ilmu pengetahuan dan teknologi di era digital Four Point Zero memiliki dampak yang besar bagi dunia pendidikan. Salah satunya adalah dengan memanfaatkan aplikasi e-learning dalam proses pembelajaran. Akan tetapi, teknologi yang digunakan dalam pembelajaran ini terlalu bergantung dengan jaringan internet. Oleh karena itu penelitian bertujuan untuk mengembangkan sebuah media berupa aplikasi e-learning berbasis andorid yang dapat digunakan secara online dan offline. Penelitian ini menggunakan rancangan penelitian dan pengembangan menggunakan model ADDIE. Untuk membuat dan menguji produk tersebut dalam hal ini aplikasi $e$ - learning berbsasis android. Prosedur Penelitian ini dilakukan melalui 6 tahapan yaitu analisis kebutuhan, tahap desaian aplikasi, pengembangan, analasisis data, evaluasi, dan pengembangan produk akhir yang siap untuk digunakan. Dari hasil uji validasi materi dan kelayakan media aplikasi yang dikembangkan sangat layak untuk digunakan.
\end{abstract}

Kata kunci: Aplikasi, Blended E-learning, Android, Offline-Online

\begin{abstract}
The development of science and technology in the digital era of Four Point Zero has a great impact on the world of education. One of them is by utilizing e-learning applications in the learning process. However, the technology used in this learning is too dependent on the internet network. Therefore, the research aims to develop a media in the form of an Android-based e-learning application that can be used online and offline. This study uses a research and development design using the ADDIE model. To create and test these products, in this case an Android-based e-learning application. Procedure This research was carried out through 6 stages, namely needs analysis, application design stage, development, data analysis, evaluation, and development of a final product that is ready to be used. From the results of the material validation test and the feasibility of the developed application media, it is very feasible to use.
\end{abstract}

Keywords: Aplication, Blended E-learning, Android, Offline-Online

\section{INTRODUCTION}

We are currently entering the digital four point zero era where the use of technology has entered various aspects of life. Almost every activity or activity or work has utilized digital technology in its implementation. Digital technology in the form of the use of computing connected to the internet makes everything unlimited. Many things can be controlled from a distance with digital technology. In addition, the impact of the Covid-19 pandemic has also contributed to changes in the pattern of human life (Ardhana Januar Mahardhani, 2020; Pantan \& Benyamin, 2020) to find solutions from the implementation of social distancing by utilizing space on digital technology. This condition also has an impact on the use of information and communication technology which results in more and more new technologies appearing in various aspects of life. Rachmad and Fragastia mentions that the system used in Android is Linux, thus providing an open platform for anyone to create their own applications (Rahmad \& Fragastia, 2017).

In the world of education, one application that is widely developed on Android is the elearning application. The e-learning application is an application used in teaching and learning activities that utilize digital technology in its implementation (Harahap, 2015). Students can access learning materials in the form of pictures, 
learning videos, powerpoints, assignments that have been prepared in the e-learning. Some of the popular e-learning used are Edmodo (Ekayati, 2018), Moodle (Polhun, Kramarenko, Maloivan, \& Tomilina, 2021), Google Classroom (Murtikusuma et al., 2019), and Quipper (El Iq Bali et al., 2021). However, the application can only be used if the android device is connected to the internet. If the internet connection is not connected then the application cannot be used. This is one of the obstacles to using e-learning applications. Where the internet network has not reached all parts of Indonesia and the price of internet quota is relatively expensive and the application used also consumes a lot of internet quota.

Siregar and Manurung in 2020 stated that research shows that there are significant differences in the creativity of prospective teacher students who apply blended learning. Thus, it can be said that blended learning has an effect on creativity (Siregar \& Manurung, 2020). Khoiroh in 2017 stated that student learning outcomes using the blended learning model were higher than student learning outcomes using the direct learning model. Students' motivation in participating in learning using the blended learning learning model is higher than the direct learning learning model. There is an interaction between blended learning and learning motivation on student learning outcomes (Khoiroh \& Anifah, 2017). The results of the research conducted by Darmawan and Nashoih, showed that the mobile learning media was declared valid and worthy of being used as a learning medium, based on the validation of media and material experts with an average score of 3.46, so it was declared feasible. While the results of the trial showed the effectiveness of the media through the pretest and posttest scores which increased by 26.71, with an average value of 52.39 for pretest and 79.10 for posttest. This figure shows that the application of mobile learning media is able to significantly improve student learning outcomes, as well as support the blended learning model (Darmawan \& Nashoih, 2019).

Based on the background described above, the researcher wants to develop a blended elearning application, which means it can be used offline and online. Online is used when students download the application on the play store available on the Android system. While offline is used to access all the material in the application in the form of documents, power points, learning videos and others that are run without using the internet.

\section{RESEARCH METHODS}

This research uses quantitative research, with the ADDIE research model (Arifin, Septanto, \& Wignyowiyoto, 2018). This research model consists of 5 stages, namely analysis, planning, development, implementation, and evaluation. In this study, researchers only carried out stages 1 to stage 3 . The analysis stage is a needs assessment process, identifying problems and conducting analysis using interview instruments to participants (15 people) Graphic Engineering students who use e-learning applications in the learning process. The design stage (blue print), namely the stage of developing an e-learning application that answers problems at the analysis stage to create an e-learning application that can be used online or offline so that when learning takes place it does not only depend on internet connections (quota). The development stage is the stage for compiling and engineering e-learning applications that have been designed so that android-based e-learning applications can be used, design research model can be seen in Figure 1. .

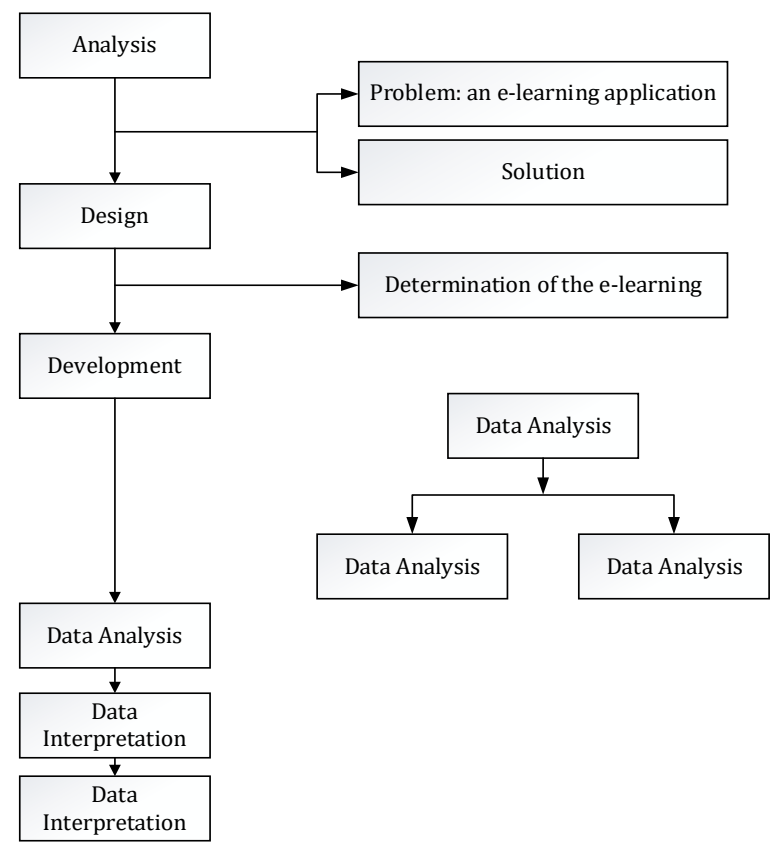

Figure 1. Research Model

\section{Types of research}

This research uses a quantitative approach . his research uses quantitative research, with the ADDIE research model. This research model consists of 5 stages, namely analysis, planning, development, implementation, and evaluation. The development of learning media contains 3 main components, namely (Hikmah, Saridewi, \& Agung, 2017). 
a. Development style

This is the basis for improving the product to be produced. Model Development model can be in the form of procedural models, conceptual models and theoretical models.

b. Development procedure

The development procedure is different from the development model because the development procedure shows the properties of the components in each development session, explains analytically the use of components in each development session and explains the bonds between components in the system.

c. Product trial.

The product trials tested were expert testing (expert validation), limited-scale trials and broadscale trials.

\section{Time and Place of Research}

This research will be carried out at the State Polytechnic of Creative Media PSDKU Medan in the Graphic Engineering Study Program. Held in May-November 2021.

\section{Research Target/Subject}

The target of this research is a product in the form of artyculate story line 3.0-based learning media that can be used online and offline specifically in the graphic material knowledge course. the population of this study were graphic engineering students totaling 15 people. while the expert validators are graphic design lecturers and lecturers who teach graphic material knowledge courses.

\section{Procedure}

The steps in designing articulate storybased learning media are as follows: The plan, in the process of making this media begins with the planning process. At this stage, first determine the purpose of the learning media created, namely learning media that can be used on-line and off-line. Design, from the information and data collected at the planning stage, the next stage you design the front page display and the articulated media page starting from the Log-in view. Design is necessary to give the site beauty. This can be a combination of unique colors, layouts, fonts used to make the web attractive and not boring for users. Figure 2 here's the media background design.

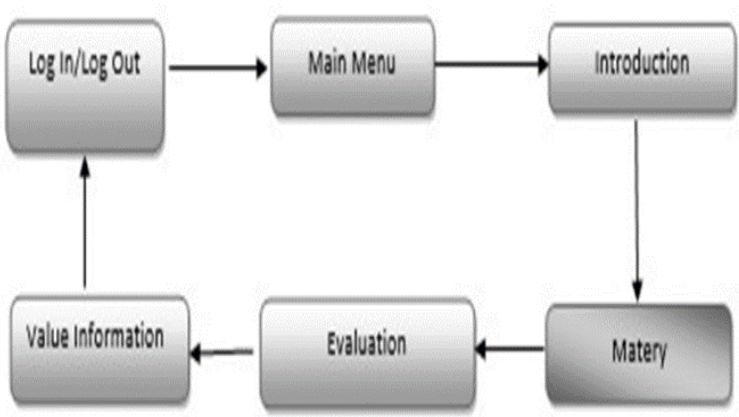

Figure 2. Designing Articulate Story-based Learning Media

\section{Data, Instruments, and Data Collection Techniques}

Data collection techniques using primary data and secondary data (Janah, Sukarelawati, \& Agustini, 2019). Primary data in the form of data on the feasibility assessment of android-based elearning application products by IT experts and the substance of the material obtained by questionnaires in the form of an assessment of the resulting e-learning application and data on the responses of lecturers and students to the material contained in the android-based e-learning application. which is generated.

\section{Data analysis technique}

Primary data and secondary data were then analyzed. The data analysis used is quantitative and qualitative. Qualitative data in the form of a questionnaire validation sheet from an expert validator containing assessments, responses, suggestions and input. The eligibility criteria for android-based e-learning applications are expressed in percentages calculated using the formula in equation 1 . While quantitative data are obtained from student perceptions through questionnaires which are then analyzed.

Presentation of eligibility value $=\frac{\text { score obtained }}{\text { maximum score }} \times 100 \%$

Table 1. Eligibility of Blended E-Learning Application Products

\begin{tabular}{lll}
\hline No & Presentage & Qualification \\
\hline 1 & $81-100$ & Very supportive \\
\hline 2 & $61-80$ & supportive \\
\hline 3 & $41-60$ & Enough supportive \\
\hline 4 & $21-40$ & less supportive \\
\hline 5 & $0-20$ & Not supportive \\
\hline
\end{tabular}

Eligibility of Blended E-Learning Application Products. Data obtained from expert validation of learning materials has weaknesses: the type of spiritual labor needed described and given examples; full working characteristics are 
described again; there are no examples of the types of unemployment. Less explanationcomplete; efforts to improve the quality of trained workersgrouped for clarity. The steps that recommended is to fix things that are not appropriate suggested material experts with additional comments is to add types of technological unemployment. The conclusion is the validation results are material declared eligible for field trials with revisions according to suggestions. Description of Expert Validation of Learning Outcome Test Instrument Materials

\section{RESULTS AND DISCUSSION}

The design of learning media based on articulate story line 3.0 was validated by 3 experts from the Design Department and Graphic Department at the State Polytechnic of Creative Media who acted as expert validators. The expert validators of this study are material validators and two lecturers as media validators. This validator assesses every component in the articulate story line 3.0-based learning media in accordance with the guidelines for assessing the feasibility of learning media from Wahono (2006). The results of the media feasibility assessment by the validator can be observed in Table 1.

Table 2. Recapitulation of Media Feasibility Assessment Results Material Aspect

\begin{tabular}{lll}
\hline \multirow{2}{*}{ No } & From Matery & Score \\
\cline { 2 - 3 } & Learning disain & 4 \\
\hline 1 & Clarity of learning objectives & 4 \\
\hline 2 & Relevance of learning objectives & 4 \\
\hline 3 & $\begin{array}{l}\text { The suitability of the material with } \\
\text { the learning objectives }\end{array}$ & 4 \\
\hline 4 & $\begin{array}{l}\text { Appropriate use of learning } \\
\text { strategies }\end{array}$ & 4 \\
\hline 5 & Interaktive & 3 \\
\hline 6 & Motivation study & 4 \\
\hline 7 & Kontekstuality & 4 \\
\hline 8 & Materi dept & 4 \\
\hline 9 & Easy to understand & 4 \\
\hline 10 & Sistematic & 4 \\
\hline 11 & $\begin{array}{l}\text { Clarity of descriptions, discussions, } \\
\text { examples, simulations and }\end{array}$ & \\
\hline & exercises & 4 \\
\hline 12 & Evaluation & \\
\hline
\end{tabular}

Table 3. Recapitulation of Media Feasibility Assessment Results Media Aspect

\begin{tabular}{|c|c|c|}
\hline \multirow{2}{*}{ No } & From Media & \multirow[b]{2}{*}{ score } \\
\hline & Soft ware aspek & \\
\hline 1 & $\begin{array}{l}\text { Effective and efficient in the } \\
\text { development and use of learning media. }\end{array}$ & 4 \\
\hline 2 & $\begin{array}{lcc}\text { Maintenace } & \text { (can } & \text { be } \\
\text { maintained/managed easily). } & \end{array}$ & 3 \\
\hline 3 & $\begin{array}{l}\text { Usability (easy to use and simple to } \\
\text { operate) with or without an internet } \\
\text { connection. }\end{array}$ & 4 \\
\hline 4 & $\begin{array}{l}\text { Compatibility (learning media can be } \\
\text { installed/run on various existing } \\
\text { hardware and software) }\end{array}$ & 4 \\
\hline 5 & $\begin{array}{l}\text { Reusable (part/all of the learning media } \\
\text { program can be reused to develop other } \\
\text { learning media) }\end{array}$ & 4 \\
\hline 6 & $\begin{array}{l}\text { Communicative (on target and } \\
\text { acceptable to the target's wishes) }\end{array}$ & \\
\hline 7 & Creative in ideas and pouring ideas & 4 \\
\hline 8 & $\begin{array}{l}\text { Clarity of descriptions, discussions, } \\
\text { examples, simulations and exercises }\end{array}$ & 4 \\
\hline 9 & $\begin{array}{l}\text { The suitability of the material with the } \\
\text { learning objectives }\end{array}$ & 4 \\
\hline 10 & $\begin{array}{l}\begin{array}{l}\text { Audio (narration, sound effects, } \\
\text { background, music) }\end{array} \\
\end{array}$ & 3 \\
\hline 11 & $\begin{array}{l}\text { Clarity of descriptions, discussions, } \\
\text { examples, simulations and exercises }\end{array}$ & 4 \\
\hline 12 & Layout Interactive & 3 \\
\hline
\end{tabular}

Based on Table 1 and Table 2 above, the calculation of each criterion is based on the media feasibility assessment guidelines. Highest score $=5$, and Lowest score $=1$

There are 4 desired classes, namely Very Good (SB), Good (B), Less Good (KB) and Not Good (TB).

Range $=$ largest data - smallest data $=5-1=4$ Interval length $(\mathrm{p})=0.5$

Based on the calculation above, it can be determined the range of scores and the criteria for the value as follows. Criteria Score Range.
a. $\quad 4.0<$ score 5.0 Very good
b. $\quad 3.0<$ score 4.0 Good
c. $\quad 2.0<$ score 3.0 Not good
d. < score 2.0 Not good

The design of the Articulate Story Learning media which has been assessed by experts and revised, is then tested on Graphic Engineering students with a sample of 15 students on a limited scale trial. Student response data stated the acceptance of the media as an articulate story linebased learning media in the form of webhtml5 which can be used in a blended manner, namely online and offline. when it reaches a score of 2.51 . Student responses were taken using a questionnaire accompanied by criticism and suggestions as a revision guide given after learning 
to use the media articulate stroy line 3.0. The results of student responses are shown in Table 3.

Table 4. Recapitulation of Student Responses on Trials Limited Scale

\begin{tabular}{lllll}
\hline No & $\begin{array}{l}\text { Response } \\
\text { Criteria }\end{array}$ & $\begin{array}{l}\text { Score } \\
\text { Range }\end{array}$ & $\begin{array}{l}\text { SStudents } \\
\text { Give } \\
\text { Feedback }\end{array}$ & $\begin{array}{l}\text { Percentage } \\
(\%)\end{array}$ \\
\hline 1 & $\begin{array}{l}\text { Very } \\
\text { Supportive }\end{array}$ & $\begin{array}{l}3,25<\text { Score } \\
\leq 4.00\end{array}$ & 10 & $66,66 \%$ \\
\hline 2 & Supportive & $\begin{array}{l}2,50<\text { Score } \\
\leq 3.25\end{array}$ & 5 & $33,33 \%$ \\
\hline 3 & Less & $\begin{array}{l}1,75<\text { Score } \\
\text { Supportive }\end{array}$ & 0 & 0 \\
\hline 4 & $\begin{array}{l}\text { No } \\
\text { Supportive }\end{array}$ & $\begin{array}{l}1<\text { Score } \leq \\
1.75\end{array}$ & 0 & 0 \\
\hline The & number of students with \\
very supportive and supportive & & 15 \\
criteria &
\end{tabular}

Based on Table 2, students gave 100\% "supportive" and "supportive" responses to the learning media using the aticulate story line 3.0. The number of respondents with a "strongly supportive" response is greater than the number of respondents with a "supportive" response. The description above explains that the learning media using aticulate story line 3.0 is well received because it reaches a score of 3.81. Furthermore, to find out the average score of student responses, it can be seen in Table 5.

Table 5. Recapitulation of Student Responses on Trials Limited Scale

\begin{tabular}{|c|c|c|c|}
\hline No & Response & $\begin{array}{l}\text { Score } \\
\text { Mean }\end{array}$ & Criteria \\
\hline 1 & Interest in using media & 3,27 & $\begin{array}{l}\text { Very } \\
\text { Supportive }\end{array}$ \\
\hline 2 & $\begin{array}{l}\text { Media according to learning } \\
\text { objectives }\end{array}$ & 3,47 & $\begin{array}{l}\text { Very } \\
\text { Supportive }\end{array}$ \\
\hline 3 & Easy-to-operate media & 3,07 & Supportive \\
\hline 4 & $\begin{array}{l}\text { Media helps understanding } \\
\text { the material }\end{array}$ & 3,00 & Supportive \\
\hline 5 & $\begin{array}{l}\text { Media can use online or } \\
\text { offline }\end{array}$ & 3,20 & Supportive \\
\hline 6 & $\begin{array}{l}\text { Media with practice } \\
\text { questions and } \\
\text { Information }\end{array}$ & 3,47 & $\begin{array}{l}\text { Very } \\
\text { Supportive }\end{array}$ \\
\hline 7 & $\begin{array}{l}\text { Media increases learning } \\
\text { motivation }\end{array}$ & 3,00 & Supportive \\
\hline 8 & $\begin{array}{l}\text { Media is } \\
\text { Indenpendently }\end{array}$ & 3,47 & $\begin{array}{l}\text { Very } \\
\text { Supportive }\end{array}$ \\
\hline 9 & $\begin{array}{l}\text { More effective and efficient } \\
\text { media }\end{array}$ & 3,27 & $\begin{array}{l}\text { Very } \\
\text { Supportive }\end{array}$ \\
\hline 10 & $\begin{array}{l}\text { Intersest in using media in } \\
\text { other materials }\end{array}$ & 3,33 & $\begin{array}{l}\text { Very } \\
\text { Supportive }\end{array}$ \\
\hline
\end{tabular}

The score for the SS answer

(Strongly Agree) is 4

The score for the answer S (Agree) is 3

The score for the KS answer (Disagree) is 2

The score for the TS answer (Disagree) is 1

Material Aspect
Total Score $=34$

Average Score $=2.88$

Criteria = Very Good

Aspects of Expert Media 1

Total Score $=34$

Average Score $=2.88$

Criteria $=$ Very Good

Expert Media Aspect 2

Total Score $=32$

Average Score $=2.66$

Criteria $=$ Very Good

Based on the ten response items that received the "very supportive" criteria, there were seven statements and 3 items with the "Supporting" criteria. so that the learning media product using the aticulate story line 3.0 developed can be accepted by the respondents.

\section{CONCLUSIONS AND SUGGESTIONS}

\section{Conclusion}

The first, That the Development of Blended E-Learning Applications Using Soft Ware Articulate Story Line 3.0 is very helpful in the process of implementing distance learning which can be done online or non-online and based on media tests and material tests concludes that Blended E-Learning Application Development With Using Articulate Story Line 3.0 Software is feasible to use. The second, Based on student responses, 90\% strongly supports and $10 \%$ supports the application of Blended E-Learning Application Development Using Articulate Story Line 3.0 Soft Ware.

\section{Suggestion}

It is hoped that this research will continue to develop and be used during the distance learning process that will be implemented. It is hoped that researchers can always upgrade any information about distance learning based on articulate story line 3.0. Hopefully this research can be an opening in the implementation and development of articulate story-based learning media.

\section{REFERENCES}

Ardhana Januar Mahardhani, M. K. (2020). Menjadi Warga Negara yang Baik pada Masa Pandemi Covid-19: Persprektif Kenormalan Baru. JPK (Jurnal Pancasila Dan Kewarganegaraan), 5(2), $\quad$ 65-76. https://doi.org/10.24269/JPK.V5.N2.2020.P P65-76

Arifin, R. W., Septanto, H., \& Wignyowiyoto, I. (2018). Pengembangan Media Pembelajaran Berbasis Video Animasi Dengan Model ADDIE 
Dalam Kegiatan Pembelajaran Blended Learning. Information Management For Educators And Professionals: Journal of Information Management, 2(2), 179-188. Retrieved from http://www.ejournalbinainsani.ac.id/index.php/IMBI/article/vie w/946

Darmawan, M. F., \& Nashoih, A. K. (2019). Pengembangan Mobile Learning Berbasis Android Pada Mata Pelajaran Bahasa Indonesia Untuk Mendukung Pembelajaran Blended Learning. Jurnal Education And Development, $\quad 7(4), \quad 14$. https://doi.org/10.37081/ED.V7I4.1315

Ekayati, R. (2018). Implementasi Metode Blended Learning Berbasis Aplikasi Edmodo. EduTech: Jurnal Ilmu Pendidikan Dan Ilmu Sosial, 4(2), 50-56.

https://doi.org/10.30596/EDUTECH.V4I2.22 77

El Iq Bali, M. M., Zamroni, Umar, Musthofa, B., Sulistiani, I. R., Dewi, M. S., ... Abdullah, D. (2021). The Effect of Quipper School Assisted Blended Learning (QSBL) on Student Motivation and Interest in Learning. Journal of Physics: Conference Series, 1899(1), 012154. https://doi.org/10.1088/17426596/1899/1/012154

Harahap, S. H. (2015). Pemanfaatan E-Learning Berbasis Lcms Moodle Sebagai Media Pembelajaran Untuk Mata Kuliah Sistem Informasi Akuntansi. Jurnal Riset Akuntansi Dan Bisnis, 15(1), 86-99. https://doi.org/10.30596/JRAB.V15I1.429

Hikmah, N., Saridewi, N., \& Agung, S. (2017). Penerapan Laboratorium Virtual untuk Meningkatkan Pemahaman Konsep Siswa. EduChemia (Jurnal Kimia Dan Pendidikan), 2(2), 186-195 https://doi.org/10.30870/EDUCHEMIA.V2I2 .1608

Janah, R., Sukarelawati, S., \& Agustini, A. (2019). Implementasi Program Pelibatan Dan Pemberdayaan Masyarakat PT. Tirta Investama Aqua Babakan Pari. Jurnal Komunikatio, 5(1), 7-10.
https://doi.org/10.30997/JK.V5I1.1692

Khoiroh, N., \& Anifah, L. (2017). Pengaruh model pembelajaran blended learning dan motivasi belajar terhadap hasil belajar siswa kelas VIII SMPN 1 Gumukmas. Jurnal Penelitian Ilmu Pendidikan, 10(2), 97-110. https://doi.org/10.21831/JPIPFIP.V10I2.139 86

Murtikusuma, R. P., Hobri, Fatahillah, A., Hussen, S., Prasetyo, R. R., \& Alfarisi, M. A. (2019). Development of blended learning based on Google Classroom with osing culture theme in mathematics learning. Journal of Physics: Conference Series, 1165(1), 012017. https://doi.org/10.1088/17426596/1165/1/012017

Pantan, F., \& Benyamin, P. I. (2020). Peran Keluarga dalam Pendidikan Anak pada Masa Pandemi Covid-19. KHARISMATA: Jurnal Teologi Pantekosta, 3(1), 13-24. https://doi.org/10.47167/KHARIS.V3I1.43

Polhun, K., Kramarenko, T., Maloivan, M., \& Tomilina, A. (2021). Shift from blended learning to distance one during the lockdown period using Moodle: test control of students' academic achievement and analysis of its results. Journal of Physics: Conference Series, 1840(1), 012053. Kryvyi Rih: IOP Publishing. https://doi.org/10.1088/17426596/1840/1/012053

Rahmad, I. F., \& Fragastia, V. A. (2017). Perancangan Navigasi Robot Berbasis Suara Menggunakan Android. Seminar Nasional Informatika (SNIf), 1(1), 320-324. Retrieved from http://ejournal.potensi-

utama.ac.id/ojs/index.php/SNIf/article/view $/ 193 / 140$

Siregar, N., \& Manurung, S. L. (2020). Pengaruh Blended Learning terhadap Kreativitas Mahasiswa Calon Guru di Universitas Negeri Medan. Edumatika: Jurnal Riset Pendidikan Matematika, 3(1), 44-51. https://doi.org/10.32939/EJRPM.V3I1.485 